\title{
VALIDITY OF OIL AND GAS LEASES
}

\author{
W. I. SUMMERS
}

The validity of oil and gas leases has been questioned by courts in several jurisdictions because of the lack of mutuality of consideration. In order to understand the theories and principles upon which these decisions are based, it is necessary to briefly trace the evolution of oil and gas leases from the infancy of the industry to the present time. The first leases for oil and gas purposes were modeled after leases for solid mineral. They were granted for a long, definite term, ranging from fifteen to ninety-nine years. If they contained a recital of an initial cash consideration, it was usually a nominal one. ${ }^{1}$ In this early period there was no steady market for the consumption of petroleum products. There was no large organization of capital engaged in the business of production. Operations were conducted by lessees of limited means, under leases of small tracts of land. Although the cost

${ }^{1}$ Chic. \& A. Co. v. U. S. Pet. Co. (1868) 57 Pa. 83 ( $\$ 1$ consideration, 20 year term, express covenant to drill in I20 days); Karnes v. Tanner (I870) $66 \mathrm{~Pa}$. 297 ( $\$ 500$ consideration, 50 year term, express covenant to drill within one year); Allison's Appeal (1874) $77 \mathrm{~Pa} 22 \mathrm{I}$ (20 year term); Brown v. Vandergrift ( 1875 ) $80 \mathrm{~Pa}$. St. I42 ( $\$ 225$ consideration, 20 year term, express covenant to drill within 60 days); Appeal of Stoughton (1878) $88 \mathrm{~Pa}$. I98 (2I year term); Monroe v. Armstrong ( 1880 ) $96 \mathrm{~Pa} 307$ (20 year term, express covenant to drill within Io days); Kitchen v. Smith (I882) Ior Pa. 452 (I5 year term, express covenant to drill within 4 months); Duke v. Hague (1884) ro7 Pa. 57 (20 year term, express covenant to drill); Brown v. Beecher (1888) I20 Pa. 590, I5 Atl. 608 (no cash consideration, 15 year term, express covenant to drill); Wash. Gas Co. v. Johnson (1889) I23 $\mathrm{Pa} .576,16$ Atl. 799 (no cash consideration, 20 year term, express covenant to drill within 6 months); Wills v. Mfrs.' Nat. Gas Co. (1889) I30 Pa. 222, I8 At1. 72I (\$I consideration, 20 year term, express covenant to drill within 90 days); Thompson $v$. Ridelsperger ( $189 \mathrm{I}$ ) I44 Pa. 416, 22 At1. 826 (I5 year term, express covenant to drill within 20 years); $M c N i s h$ v. Stone (I879) I52 Pa. 457, 25 Atl. 732 (no cash consideration, 99 year term, express covenant to drill within 6 months); Duffield $v$. Rosenzweig (I89I) I44 Pa. 520, 23 Ati. 4 (I5 year term, express covenant to drill within 30 days); McKnight $v$. Mfrs.' Nat. Gas Co. (1892) I46 Pa. I85, 23 Atl. I64 ( $\$ 1$ cash consideration, 20 year term, express covenant to drill within I8 months); Venture Oil Co. $v$. Fretts ( 1893 ) I52 Pa. 45I, 25 Ati. 732 (20 year term, express covenant to drill within six months); Sauders v. Sharp (I893) $153 \mathrm{~Pa}$. 555, 25 Atl. 524 (20 year term, express covenant to drill in one year); Nesbit v. Godfrey (I893) I55 Pa. 251, 25 Atl. 62r (\$75 cash consideration, 2I year term); Wood County Pet. Co. v. W. Va. Trans. Co. (I886) $28 \mathrm{~W}$. Va. 210 (I5 year term, express covenant to drill within 60 days); Wagner v. Mallory (I902) I69 N. Y. 50r, 62 N. E. 584 (40 year term); Pet. Co. v. Coal, Coke \& $M f g$. Co. (1890) 89 Tenn. 38I, I8 S. W. 65 (no cash consideration, 99 year term, covenant to test the property within three years). But some of the earlier leases stated no definite term, see Funk $v$. Haldeman (I866) $53 \mathrm{~Pa} 229$; Dark v. Johnston (I867) $55 \mathrm{~Pa}$. I64; Rynd v. Rynd Oil Co. (1869) $63 \mathrm{~Pa}$. 397; Union Pet. Co. v. Bliven Pet. Co. (1872) 72 Pa. I73. 
of drilling wells in the shallow sands of the Pennsylvania field were not so great as at present, yet, considering the amount of capital of the lessee, the uncertainty of markets and transportation, an over-estimation of the physical characteristics of oil and gas, and the lack of scientific knowledge available for the location of wells, the business was a highly speculative one. The controlling motive which induced the making of these leases on the part of the lessor and lessee undoubtedly was the thought of immediate production and the securing of their respective shares of the oil and gas. The leases of this period, therefore, usually contained recitals to the effect that they were made in consideration of the covenants of the lease. The principal covenants to which this recital referred were those on the part of the lessee for immediate development to "success or abandonment" and the payment of royalties. ${ }^{2}$

The courts in construing the oil and gas leases of this period in the light of the above mentioned facts and conditions evolved four principles of construction, namely; that the prospective royalties are the moving consideration to the lessor which supports the lease $;^{3}$ in absence of a covenant for early development a condition is implied that the lessee develop within a reasonable time on the penalty of a forfeiture of his

\footnotetext{
${ }^{2}$ See cases cited supra in note $\mathrm{I}$.

${ }^{3}$ Funk v. Haldeman, supra note I; Huggins v. Daley (I900, C. C. A. 4th) 99 Fed. 606; Steelsmith v. Gartlan (1898) 45 W. Va. 27,29 S. E. 978, 44 L. R. A. I07; Venture Oil Co. v. Fretts, supra note I; Crawford v. Ritchey (I897) 43 W. Va. 252, 27 S. E. 220 ; Plummer v. Hillside Coal Co. (I894) 160 Pa. 483, 28 At1. 853; Kelley v. Keys (I906) 213 Pa. 295, 62 Atl. 9II; Foster v. Elk Fork O. \& G. Co. (I898 C. C. A. 4th) 90 Fed. 178; Childers v. Neely (I899) 47 W. Va. 70, 34 S. E. 825; Lawson v. Kirchiner (I90I) 50 W. Va. 344, 40 S. E. 344; Parish Fork Oil Co. v. Bridgewater Gas Co. (I902) $5 \mathrm{I}$ W. Va. 583, 42 S. E. 655; Lowther Oil Co. v. Miller-Sibley (x903) 53 W. Va. 501, 44 S. E. 422; Headley v. Hoopengarner (I906) 60 W. Va. 626, 55 S. E. 144; Florence Oil Co. v. Orman (1903) ig Colo. App. 79, 73 Pac. 628; Fed. Oil Co. v. Western Oil Co. (I902, C. C. D. Ind.) II2 Fed. 373, aff'd (I902) I2I Fed. 674; Rich v. Doneghey (I9I8) 7I Okla. 204, I77 Pac. 86, 3 A. L. R. 352, dissent, Owen, J.; Nat'l. O. \& P. L. Co. v. Teel (1902) 95 Tex. 586, 68 S. W. 979; Gadbury v. Ohio \& Ind. Gas Co. (I903) I62 Ind. 9, 67 N. E. 259, 62 L. R. A. 895; Cowan v. Radford Iron Co. (I887) 83 Va. 547,3 S. E. 120; Knight v. Ind. C. \& I. Co. (1874) 47 Ind. Iro, I7 Am. Rep. 692; Roberts v. McFaddin (I903) 32 Tex. Civ. App. 47, 74 S. W. IIr; Guffey Pet. Co. v. Oliver (I904, Tex. Civ. App.) 79 S. W. 884; Witherspoon v. Staley (Igr3, Tex. Civ. App.) I56 S. W. 557; Smith v. Guffey (19I3, C. C. A. 7th) 202 Fed. 109 ; Ozens v. Corsciana Pet. Co. (1914, Tex. Civ. App.) I69 S. W. I93; Long v. Sun Co. (I9I3) I32 La. 601, 6r So. 684; Gt. Westerm Oil Co. v. Carpenter (I906) 43 Tex. Civ. App. 229, 95 S. W. 57; Dill v. Fraze (1907) 169 Ind. 53, 79 N. E. 97 I; Ohio Oil Co. v. Detamore (I905) I65 Ind. 243 , 73 N. E. 907 ; Jennings-Heywood Synd. v. Houssiere-Latreille Oil Co. (I907) Irg La. 793, 44 So. 481; Murray v. Barnhart (1906) II7 La. 1023, 42 So. 492 ; Mansfield Gas Co. v. Alexander (I9Ix) 97 Ark I67, I33 S. W. 837; Berry v. Frisbie (1905) I20 Ky. 337, 86 S. W. 558; Bay St. Pet. Co. v. Penn Lubricating Co. (I905) I21 Ky. 637, 87 S. W. I102; Flanagan v. Marsh (1907, Ky.) I05 S. W. 424 ; Bettman v. Harness (1896) 42 W. Va. 432,26 S. E. 271.
} 
lease ; 4 equity will enforce a forfeiture of an oil and gas lease contrary to the usual rule that equity abhors a forfeiture $; 5$ oil and gas leases are construed in favor of the lessor contrary to the common law rule under which they would be construed against him. ${ }^{6}$

Perhaps no one realized the future of petroleum products, yet, with the gradual demand for them, it was foreseen by some that a growing and stabilized market could be supplied only by well-regulated and steady production. This, in turn, coutld only be accomplished by the organization of capital into units of sufficient strength to permit the.leasing of large tracts of land, to hold, prospect and develop as the conditions of market or certainty of production warranted. But these objects could not be accomplished if the lessee was bound by a duty of immediate development of each tract under lease or have the liability of loss of his leases for failure to perform this duty.

These conditions necessitated a change in the lease relieving the lessee from the necessity of immediate development. To accomplish this result a new type of drilling clause was evolved, which later came to be known as the "drill or pay" clause." By this clause, the lessee covenanted to drill or commence drilling a well within a certain time, dependent somewhat upon the proved or unproved character of the territory for oil and gas, or in lieu thereof to pay a delay rental until such well was drilled. In connection with the "drill or pay" clause there was usually a provision for forfeiture of the lease for failure of the lessee to drill or pay. This type of lease proved satisfactory for a time, due largely to a mistake on the part of both the lessors and the

'McKnight v. Mfrs.' Nat. Gas Co., supra note I; Klepner v. Lemon (1896) 176 Pa. 502, 35 Atl. 109; Aye v. Phila. Co. (1899) I93 Pa. 45I, 44 Atl. 555; Allegheny Oil Co. v. Snyder (1900) Io6 Fed. 764; Harris v. Ohio Oil Co. (I897) 57 Ohio St. II8, 48 N. E. 502; Gadbury v. Ohio \& Ind. Gas Co., supra note 3; Consumers' Gas Trust Co. v. Littler (I904) I62 Ind. 320, 7o N. E. 363; Brewster v. Lanyon Zinc Co. (1905, C. C. A. 8th) I40 Fed. 8or; Parish Fork Oil Co. v. Bridgewater Gas Co., supra note 3; Guffey Petroleum Co. v. Oliver, supra note 3; Logan Nat. Gais Co. v. Gt. So. G. \& O. Co. (1903, C. C. A. 6th) 126 Fed. 623; Kellar v. Craig (rg03. C. C. A. 4th) I26 Fed. 630; Acme Oil Ca. v. Williams (I903) I40 Calif. 68I, 74 Pac. 296; Phillips v. Hamilton (1908) I7 Wyo. 4I, 95 Pac. 846; Vendocia Oil Co. v. Robinson (I905) 7I Ohio St. 302, 73 N. E. 222; Koch's \& Balliett's Appeal (I88o) $93 \mathrm{~Pa}$ 434; Powers v. Bridgeport Oil Co. (rg09) 238 III. 397, 84 N. E. 38I.

${ }^{5}$ Brown v. Vandergrift (1875) $80 \mathrm{~Pa}$. 142; Munroe v. Armstrong (1880) 96 Pa. 307; Parish Fork Oil Co. v. Bridgewater Gas Co., supra note 3; Brewster v. Lanyon Zinc Co., stupra note 4; Guffey Pet. Co. v. Oliver, supra note 3.

-Allison's Appeal, supra note I; Brozen v. Vandergrift, supra note 5; Galey v. Kellerman (I889) I23 Pa. 49I, I6 Atl. 474; Western Pa. Gas Co. v. George (1894) I6I Pa. 47, 28 Atl. I004; Kleppner v. Lemon (I896) I76 Pa. 502, 35 Atl. I09; Kennedy v. Crawford (I891) I38 Pa. 561, 21 Atl. 19; Steelsmith v. Gartlan, supra note 3; Bettman v. Harness, supra note 3 .

'See Appeal of Wills (1889) 130 Pa. 235, I8 At1. 724, and Ray v. Western Pa. Gas Co. (I89I) I38 Pa. 576, $20 \mathrm{Atl}$. I065, for early forms of the "drill or pay" clause. 
lessees of their true legal relations thereunder. They acted upon the assumption that a failure to drill or pay delay rental by the lessee brought the lease to an end. But in I889, the Supreme Court of Pennsylvania held that the forfeiture provision in the "drill or pay" lease was for the benefit of the lessor only, and that the lessor, in the event that the lessee had failed to drill or pay, could waive the forfeiture and sue for the rent for the term of the lease. ${ }^{8}$ After this decision it was apparent that the "drill or pay" lease with a long definite term was not what the interest of the business from the standpoint of the lessee demanded. Under such a lease, he might find himself bound to pay a delay rental for a long period of years, although the land had long since been proven worthless for oil and gas purposes. Perhaps the first measure of relief from this situation was accomplished by shortening the length of the fixed term to five or ten years, with a clause providing that in the event of production within that time the lease should continue as long as oil and gas were produced in paying quantities. But even this change was not wholly satisfying from the standpoint of the lessee. Land might prove worthless for oil and gas purposes by a test made in the vicinity, and he would still be bound to pay rentals for five or ten years without any hope of return.

Relief from this burden was accomplished in two ways. One was by the addition of a "surrender" clause" to the "drill or pay" clause, and the other, by the use of the "unless"10 drilling clause. Under either of these types of leases, the lessee had the power to terminate the lease when the land proved to be of no value for oil and gas purposes.

Where the "or" type of drilling clause was used in conjunction with the "surrender" clause, the lessee was either bound to drill or pay until some operative act by either the lessor or the lessee brought the lease to an end. If the lessee failed to drill or to pay, the lessor might declare a forfeiture and cancel the lease, or he might waive the forfeiture and sue for the rent. The lessee could terminate the lease and escape these obligations only by the act of surrendering it, having first paid up the accrued rentals, and tendered the cash consideration required as condi-

- Galey v. Kellerman, supra note 6.

"And it is further agreed that the second parties, their heirs or assigns, shall have the right at anytime to surrender up this lease, and be released from all moneys due and conditions unfulfilled; then and from that time this lease and agreement shall be null and void and no longer binding on either party." "Surrender" clause in Eclipse Oil Co. v. South Penn Oil Co. (1899) 47 W. Va. 84, 86,34 S. E. $923,924$.

so "Provided, however, that this lease shall become null and void, and all rights thereunder shall cease and determine, unless a well be completed on the premises within one year from the date hereof, or unless the lessee shall pay at the rate of three hundred and fifty dollars quarterly in advance for each additional three months such completion is delayed from the time above mentioned for the completion of such well, until a well is completed." "Unless" drilling clause used in Snodgrass v. South Penn Oil Co. (I900) 47 W. Va. 509, 35 S. E. 820. 
tion precedent to the exercise of his option to surrender. On the other hand, the "unless" lease terminated by its own terms if the lessee failed to drill within the exploratory period. The only act required by the lessee to bring about such termination was the mere failure to either drill or pay. The lessee was not liable for rent, and the lessor was under no duty to declare a forfeiture. The lessee might, however, renew the lease from time to time by a periodical payment of rent in advance.

The introduction of the "drill or pay" clause with the "surrender" clause and the "unless" clause brought about another change in leases. 'The lessor could no longer depend upon the lessee's covenant for immediate development, and the payment of royalties as consideration for his grant to the lessee. Therefore, by way of inducement to him, there was instituted the practice of paying an initial cash consideration of more than a nominal sum. This amount depended largely upon the prospective value of the land for oil and gas purposes. The continuance of this practice may have been to some extent affected in some jurisdictions because the courts questioned the sufficiency of a nominal consideration to support leases of the "drill or pay" or "unless" type.

While the foregoing discussion shows that since the beginning of the oil and gas industry there has been a constant change in the terms of oil and gas leases to meet the conditions of the industry, with the result of developing the two standard types known as the "drill or pay" and the "unless" lease, yet the litigation shows that by no means have all of the questions of validity of leases been concerned with these standard types. A lease may not recite a cash consideration, and if it does, it may be nominal, or substantial, paid or unpaid; the term may be long, short, or for an indefinite time; the drilling clause may contain an express covenant for immediate development, may employ the "or" clause, with or without the "surrender" clause, the "unless" clause, or contain no covenant at all for development, except such as is implied by the courts; the "surrender" clause when used may not require a consideration as condition precedent to its exercise, or it may require the payment of a nominal or a substantial sum, or may have a further condition attached that it becomes void upon the bringing of any suit by the lessee to enforce the lease. Considering the above clauses as the ones upon which the courts have usually tested the validity of oil and gas leases from the standpoint of mutuality of consideration, one can readily appreciate the variety of situations which might arise from the possible combinations of them. The situations which have arisen, however, as will appear by the discussion to follow, have not been of great variety.

The wave of litigation, wherein the validity of oil and gas leases was seriously questioned because of their optional features, had its beginning a short time before I900. These leases were attacked upon two theories. The first being that under the "drill or pay" lease with "sur- 
render" clause, or the "unless" lease, the estate created might be brought to an end at the option of the lessee, it was likewise terminable at the option of the lessor. The second theory was that since the oil and gas lease, because of the fact that it was an executory contract, unperformed because the consideration moving to the lessor was the promise of the payment of royalties and since because of the presence of the "surrender" clause in the "or" lease or under the "unless" lease the lessee was not bound to perform the contract, it fell within that maxim, that: "Contracts unperformed, optional as to one of the parties, are optional as to both." And therefore, because lacking in mutuality of consideration, was void.

The foundation for this first line of reasoning was unwittingly laid by Lord Coke in his Commentary on Littleton. Littleton ${ }^{11}$ stated that, "Tenant at will is, where lands or tenements are let by one man to another, to have and to hold to him at the will of the lessor, by the force of which lease the lessee is in possession." This definiton was followed by Blackstone, ${ }^{12}$ Kent $^{13}$ and other authorities. ${ }^{14}$ But Lord Coke in commenting upon this statement in Littleton, after remarking that a lease at the will of the lessor was implied in law to be at the will of the lessee also, added: "And so it is when the lease is made to have and to hold at the will of the lessee, this must also be at the will of the lessor; and so are all the books that seem prima facie to differ, cleerly reconciled."15

This statement by Coke has been explained by Leake, "as meaning a lease without livery or other sufficient conveyance of a freehold estate." If not so explained, Coke's statement is directly contrary to the law as established by the cases in England and in this country, for it is well settled that a grant of an estate in fee, for life or for years, with an added power in the lessee or grantee to terminate the estate at will, is not an estate at the will of the lessor or grantor also, but simply an estate in the grantee or lessee in fee, for life or for years with power to terminate it. ${ }^{17}$ But despite the explanation as to the meaning of

$"$ Coke, Littleton sec. 68.

${ }^{13} 2$ Blackstone, Commentaries, $*_{445}$.

${ }^{13} 4$ Kent, Commentaries, *IIr.

${ }^{14}$ I Leake, Land Law (1874) 206; Williams, Real Property (22d ed. 19r4) 509; I Tiffany, Real Property (2d ed. 1920) secs. 60, 6I; I Tiffany, Landlord and Tenant (r9ro) sec. I3; I Washburn, Real Property (6th ed. 1902). sec. 762; 2 Reeves, Real Property (1909) sec. 659.

${ }^{15}$ Coke, loc. cit.

${ }^{10}$ I Leake, op. cit. 206 note b. See also 2 Reeves, loc. cit.; I Tiffany, Real Property (2d ed. I920) sec. 6I; Effinger v. Lewis (1859) $32 \mathrm{~Pa} .367$.

${ }^{17}$ I Tiffany, Real Property supra, secs. 6Ic, 32, 59c, 93; Beeson v. Burton (I852, C. P.) I2 C. B. 647, I36 Eng. Rep. I057; In re King's Leasehold Estates (1873) L. R. I6 Eq. 521; Zimbler v. Abrahams [1903] I K. B. 577; Lewis v. Reed (I88I) 74 Ind. 433; Effinger v. Lezeis, supra note $16 ;$ Ely v. Randall (I897) 68 Minn. I77, 70 N. W. 980; Gilmore v. Hamilton (I882) 83 Ind. I96; 
Lord Coke's dictum, some American courts have been misled by it. ${ }^{18}$ In Cheever $v$. Pearson, ${ }^{19}$ where a grantee's interest in certain lands was terminable by his removal of a building thereon, it was held to be a lease terminable at the will of the lessee. But the court added: "This being so, the rule is settled, and has been unquestioned from Lord Coke's time to the present, that every lease at will must, in law, be at the will of both parties. Therefore when a lease is made to hold at the will of the lessee, it must also be at the will of the lessor."20 In Doe v. Richards, ${ }^{21}$ where an instrument gave one an interest in land at his own will, the court quoted the dictum of Lord Coke and relying upon it and Cheever v. Pearson, supra, held that the interest of the tenant was terminable at the will of the lessor or his assigns by notice to quit. In Knight $v$. Indiana Coal \& Iron Co. ${ }^{22}$ the action was one to quiet title by a lessor of coal lands as against his lessee under a lease in which the lessee had a power to surrender. The court held that the plaintiff was entitled to the relief sought on the ground that since the interest created was at the will of the lessee it was at the will of the lessor also. The court relied upon Doe v. Richards, supra, and the authorities cited therein, and boldly asserted that "a lease or estate which is at the will of one of the parties is equally at the will of the other party," and quoted from Blackstone and Kent to prove this statement without seeming to note that the statements of those writers were based upon an estate at the will of the lessor. ${ }^{23}$

In direct reliance upon Knight v. Indiana Coal \& Iron Co., supra, and Doe v. Richards, supra, the Virginia court in Cowan v. Radford Iron Co., ${ }^{24}$ where under a lease for mining ore the lessee had the power to terminate the lease at any time by the removal of machinery and build-

Thomas v. Thomas (I866) I7 N. J. Eq. 356; Warner v. Tanner (I882) 38 Ohio St. II8; Thompson v. Baxter (I909) I07 Minn. I22, I19 N. W. 797, 21 L. R. A. (N. S.) 575, and note; Tiffany, Landlord and Tenant (IgIo) sec. 13, note 362 .

${ }^{28}$ Cheever v. Pearson (1834) 33 Mass. 266; Doe v. Richards (1853) 4 Ind. 374;

Knight v. Ind. C. \& I. Co. (1874) 47 Ind. I05; Western Trans. Co. v. Lansing (I872) 49 N. Y. 499 ; Cowan v. Radford Iron Co. (1887) 83 Va. 547, 3 S. E. 120.

${ }^{13}$ Supra note 18 .

${ }^{20}$ Here the Massachusetts court cited Coke, loc. cit.

${ }^{21}$ Supra note I8.

Supra note $\mathrm{I} 8$.

${ }^{23}$ The court here quoted 2 Blackstone, loc. cit. supra note 12, where it is said "But every estate at will, is at will of both parties, landlord and tenant; so that either of them may determine his will, and quit his connection with the other at his own pleasure." Had the learned court read the second sentence above the one quoted he would have surely understood that in the sentence quoted, Blackstone by "estate at will" clearly meant an estate at the will of the lessor. The same may be said of the reference to the quotation from 4 Kent, loc. cit. supra note I3; I Washburn, Real Property (3d ed. 1868 ) 503 is relied upon and is really misleading, for the author citing Coke, loc. cit. supra note 15 , and Smith, Landlord and Tenant I5, says: "An estate at will in lands is that which a tenant has by entry thereon under a demise to hold during the joint wills of the parties to the same."

${ }^{24}$ Silpra note I8. 
ings placed upon the land, held that in a bill by the lessor to cancel or rescind the lease, the lessor should recover because being at the will of the lessee the estate was equally at the will of the lessor.

The first oil and gas case in which this erroneous dictum of Coke was adhered to was Eclipse Oil v. South Penn Oil Co. ${ }^{25}$ In that case the lease was for the term of three years and as long thereafter as oil and gas could be produced in paying quantities. The lease did not contain an acknowledgment or recital of a cash consideration but did contain a recital that it was made in consideration of the "covenants and agreements hereinafter mentioned." Such covenants were the promises of the lessee to pay oil royalties and gas rentals and to drill a test well upon the premises within six months, or in lieu thereof, thereafter to pay one dollar per acre per annum until such well was completed. The lease also contained a clause providing for forfeiture of the lease if the well was not drilled or the rental paid, and a clause giving power to the lessee to surrender the lease at any time and be thereafter released from all obligations. The lessee did not drill during the first six months, but he did pay the delay rental within time so that there were no grounds for forfeiture. The lessor, however, about a year after the first lease, made a second lease and the senior lessee brought a bill in equity against the junior lessee seeking to enjoin him from drilling for oil and gas. One of the principal grounds upon which the court held that the senior lessee was not entitled to the relief sought was that because of the "surrender" clause in the lease giving the lessee power to terminate the lease at will the interest created was merely a tenancy at will and was equally terminable by the lessor, and that the act of making the second lease by which that will was expressed terminated the prior lease. In reaching this conclusion the court relied upon Doe $v$. Richards, Knight v. Indiana Coal \& Iron Co., and Cowan v. Radford. Iron Co., supra, and very naturally made the same errors as were made in those cases. ${ }^{26}$ In later cases the West Virginia court has held that similar leases containing a recital or acknowledgment of an initial cash consideration did not create a tenancy at will. Viewed as a contract, of course the cash consideration made the lease a binding option and prevented the lessor from cancelling it, but if the surrender clause had had the effect contended for in Eclipse Oil Co. v. South Penn Oil Co.,

${ }^{25}$ Supra note 9. See also Trees v. Eclipse Oil Co. (1899) 47 W. Va. I07, 34 S. E. 933 , where it was held that a similar lease creating merely a tenancy at will was terminated by the death of the lessor.

${ }^{20}$ In speaking of the interest created by the lease the court said: "It therefore created a mere estate at their will, and, being at their will, it was at the will of the lessor, also. There is no escape from this conclusion, and it has been the law, undisputed, from time immemorial. B1. Comm. I45; 4 Kent, Comm. III; Washburn, Real Prop. 505; Co. Inst. 55a." 47 W. Va. at p. 95, 34 S. E. at p. 928. This shows that the court was completely deceived by its slavish adherence to the Indiana and Virginia cases. 
supra, it is difficult to imagine how the payment of one dollar or a thousand dollars could make any change. ${ }^{27}$

In Federal Oil Co. v. Western Oil Co., ${ }^{28}$ the lease stated no term, acknowledged a consideration of $\$ \mathrm{I}$, contained an "unless" drilling clause and a "surrender" clause. The lessee did not commence drilling within the exploratory period, which was only one day, but did pay or tender the monthly installments to keep the lease alive. The lessor refused to receive the eighth payment, made a new lease and placed the lessee in possession. The first lessee brought a bill in equity to remove the cloud upon his title and for injunction. This relief was denied upon several grounds. One of them was that since the lessee by the surrender clause had power to terminate the lease the interest created was a tenancy at will and that the lessor likewise had such power which he had exercised by making the second lease and placing the lessee in possession. For this holding the court relied upon Knight v. Indiana Coal \& Iron Co., supra.

But in Brown v. Fowler, ${ }^{29}$ decided in the same year as Federal Oil Co. v. Western Oil Co., supra, the Ohio Court took a different view. The lease, which was for a term of two years and as long thereafter as oil and gas was found in paying quantities, provided that it could not extend beyond twenty five years, acknowledged the receipt of $\$$ I consideration, contained an "unless" drilling clause and a "surrender" clause. Before the end of the two year period the lessor made a similar lease to a second lessee, claiming that the first lease was void. The assignees of the first lease commenced an action against the second lessee and the lessor to enjoin them from drilling on the premises, and the second lessee filed a cross petition to prevent the senior lessee from

"Pyle v. Henderson (1909) 65 W. Va. 39, 63 S. E. 762; Harness v. Eastern Oil Co. (IgOI) $49 \mathrm{~W}$. Va. 250, 38 S. E. 662; Lowther Oil Co. v. Guffey (Ig03) 52 W. Va. 88, 43 S. E. Ior ; Lovett v. Eastern Oil Co. (I9II) 68 W. Va. 667, 70 S. E. 707, Ann. Cas. I9r2B, 360. In the last case cited the court in speaking of Eclipse Oil Co. v. South Pem Oil Co. and Trees v. Eclipse Oil Co., said: "Those cases proceed upon the idea that there was no binding leases; that there was no obligation, no promise on the part of the lessee to pay money or to do anything, and a privilege to surrender the leases without payment of anything, at mere will; that they conferred only an estate at the will of the lessee, and that, the estate being one at will, it might be terminated by either party; that there was no consideration for the lease. $* * *$ In the lease before us we find a valuable consideration paid, as it recites the payment of $\$ \mathrm{I}$ down. $* * *$ But that $\$ \mathrm{I}$ is not the only consideration; for the lease provided that the lessee shall drill wells, and from them pay royalty, or on the failure to do that pay $\$ 90$ per year. $* * *$ So that the lessee by not exercising the privilege of surrender, paid large amounts as yearly rental, accepted by Lovett this was valuable consideration, in addition to the $\$ \mathrm{I}$, and would bar Lovett from holding the lease a mere option without consideration, a mere estate at will terminable whenever Lovett chose."

${ }^{23}$ Supra note 3 . The Court did not seem to notice that the unless drilling clause gives the lessee the option to terminate the estate at will as well as does the surrender clause.

(I902) 65 Ohio St. 507, 63 N. E. 76. 
drilling. The controversy was decided against the senior lessee on the ground that his lease had expired by its own terms, but it was strongly urged that the first lease was a tenancy at will and therefore terminable by the lessor by his act of making the second lease. The court held that the lease did not, because of the surrender clause or the optional nature of the "unless" drilling clause, make the interest created a tenancy at will terminable by the will of either party. It pointed out very clearly the error made in Doe v. Richards, supra, and persisted in other cases discussed above, had been due to the fact that in making use of the statement, found in Blackstone, Kent and other authorities, that a tenancy at will is terminable at the will of either party, the courts had overlooked the fact that this rule of law is based upon the assumption that a tenancy at the will of the lessor had been created, and not, as in an oil and gas lease with a "surrender" clause where in effect there was a tenancy for years with a power to terminate the lease before the expiration of the term by the lessee only. This error was further explained in a later Ohio case. ${ }^{30}$

Following the lead of the Ohio court in Brown v. Fowler, supra, the Federal courts and the courts of the other states, except in some early decisions in Oklahoma and Texas, the erroneous doctrine that an oil and gas lease giving the lessee a power to surrender created a tenancy at will terminable by the lessor at any time, has not been recognized. ${ }^{31}$ In Indiana, where the lease was practically the same as that in Federal Oil Co. v. Western Oil Co., supra, Knight v. Indiana Coal \& Iron Co., supra, was distinguished on the ground that the subject matter in the earlier Indiana case was solid minerals and the principles there announced were not applicable to a lease for oil and gas. ${ }^{32}$ In Illinois,

${ }^{30}$ Cent. Ohio Nat. G. \& F. Co. v. Eckert (I904) 70 Ohio St. I27, 7 I N. E. 283. The court here relied upon Effinger v. Lezeis (1859) $32 \mathrm{~Pa} .367$ to explain the dictum of Lord Coke.

${ }^{3}$ Rechard v. Cowley (x918) 202 Ala. 337, 80 So. 4I9; Dunway v. Galbraith (I919) r39 Ark. 580, 214 S. W. 33; Lazerence v. Mahoney (1920) I45 Ark. 3ro, 225 S. W. 340 ; Rogers v. Magnolia O. \& G. Co. (1922) 156 Ark. 103, 245 S. W. 802; Dormon Farms Co. v. Stewart (I923) I57 Ark. I94, 247 S. W. 778; Grooms v. Minton (1923) I58 Ark 448, 250 S. W. 543; New American O. \& M. Co. v. Troyer (1905) I66 Ind. 402,76 N. E. 253,77 N. E. $739 ;$ Poe v. Ulrey (1908) 233 Ill. 56, 84 N. E. 46; Dickey v. Coffeyville V. B. \& T. Co. (1904) 69 Kan. 106, 76 Pac. 398; Pittsburg V. P. \& B. Brick Co. v. Bailey (Igo7) $76 \mathrm{Kan}$. 42, 90 Pac. 308; Brewster v. Lanyon Zinc Co., supra. note 4; Lindley v. Raydure (19I7, E. D. Ky.) 239 Fed. 928, aff'd; Raydure v. Lindley (Igr8, C. C. A. 6th) 249 Fed. 675; Shaffer v. Marks (I917, E. D. Okl.) 24I Fed. I39; Dozeney v. Gooch (I9I4, E. D. Ok1.) 240 Fed. 527; McCullongh v. Smith (1917, C. C. A. 8th) 243 Fed. 823 ; Leeper v. Neely (I923, C. C. A. 6th) 293 Fed. 967; Miller v. Union G. \& O. Co. (I924, C. C. A. 6th) 295 Fed. 27 ; Northwestern O. \& G. Co. v. Branine (IgI8) 7I Okl. I07, I75 Pac. 533, 3 A. L. R. 344; Rich v. Doneghey supra note 3; Corsciana Pet. Co. v. Owens (I920) Iro Tex. 568, 222 S. W. I54; Lovett v. Eastern Oil Co. (I9II) 68 W. Va. 667, 7o S. E. 707, Ann. Cas. I9IaB, 360; Hinerman v. Baldzin (I923, Mont.) 21 5 Pac. II03.

${ }^{2}$ New American O. \& M. Co. v. Troyer, supra note 31 . 
in reliance upon Ohio and Indiana cases, the court held that a surrender clause in a "drill or pay" lease made on the payment of one dollar initial consideration did not create a tenancy at will. ${ }^{33}$ The same view has been expressed in Kansas, ${ }^{34}$ and in Alabama ${ }^{35}$ on authority of the Kansas cases. The Federal courts in a number of cases have either impliedly or expressly repudiated the tenancy at will doctrine. ${ }^{36}$

In Raydure v. Lindley, Judge Cochran, in an able and exhaustive opinion, holds that the surrender clause in an oil and gas lease does not effect a tenancy at will in the lessee but an estate on limitation. ${ }^{37}$

In Oklahoma, while perhaps there had been no express adoption of the theory that an oil and gas lease with power in the lessee to terminate at will, amounted to a tenancy at will, yet in Kolachny $v$. Galbreath ${ }^{38}$ the court refused specific performance of such a lease on the authority of Federal Oil Co. v. Western Oil Co., supra. In Brozen v. Wilson, ${ }^{30}$ the Oklahoma court, in holding that the initial cash consideration for a

3 "The surrender clause in this lease gave to the lessee an option to surrender it before the expiration of the term, but it did not give to the lessors an option to compel a surrender. Such options and contracts are not invalid in the law, and they do not create a tenancy at will. Brown v. Fowler (1902) 65 Ohio St. 507, 63 N. E. 76; New American O. \& M. Co. v. Troyer (I905) I66 Ind. 402, 76 N. E. 253,77 N. E. 739." Poe v. Ulrey (I908) 233 Ill. 56, 84 N. E. 46.

24 "The lease before us does not create what may be likened to an estate at will, and permit the lessee at his option to terminate the lease at any time. The lessee could not arbitrarily declare that a profitable gas or oil well was not paying, and thus satisfy the condition of the lease above set out respecting surrender." Dickey v. Coffeyzille v. B. \& T. Co., supra note 3I. See also Pittsburg V.P. \& $B$. Brick Co. v. Bailey, supra note $3 \mathrm{I}$.

${ }^{35}$ Rechard v. Cowley, supra note $3 \mathrm{r}$.

${ }^{30}$ See federal cases cited supra in note $3 \mathrm{I}$.

${ }^{27}$ "The other formula or epigram had in mind is after the same order but more specific. It is that a tenancy at the will of one party is at the will of the other. The position is that by virtue of the surrender clause the holding by the lessee under these leases was a tenancy at will; i. e., at the will of the lessee, and hence at the will of the lessor as well. But such was not the nature of the holding of the lessee thereunder. He was not a tenant at will. He had no right to hold thereunder, as long as he willed. In no contingency could he hold for the purpose of exploration longer than ro years, or, if oil and gas were found, for a longer time than they could be produced. If either holding was subject to a condition subsequent, it might be terminated short of the period for which it was to last by the happening thereof, and possibly the holding for the purpose of exploration might be terminated by the test well proving dry. The surrender clause merely provided another contingency for terminating the holding short of such period. So far, then, the estates granted were not estates at will, but estates on limitation." Sicpra note $3 I$.

${ }^{33}$ (1910) 26 Okla. 772, I10 Pac. 902, 38 L. R. A. (N. S.) 45I; see also Frank Oil Co. v. Belleview Gas \& Oil Co. (I9II) 29 Okla. 7Ig, II9 Pac. 260, 43 L. R. A. (N. s.) 479; Superior O. \& G. Co. v. Mehlin (IgIo) 25 Okla. 809, 108 Pac. 545; Hill O. \& G. Co.v. White (I9I6) 53 Okla. 748, 57 Pac. 710; Melton v. Cherokee O. \& G. Co. (1918) 67 Okla. 247, I70 Pac. 691; Lima O. \& G. Co. v. Pritchard (I923) 92 Okla. II3, 218 Pac. 863.

${ }^{20}$ (Ig16) 58 Okla. 392, I60 Pac. 94, L. R. A. I917B, I I84. 
lease supported only the exploratory period and after that the lessor might cancel, refused to follow the Ohio, Illinois and Kansas cases where the tenancy at will doctrine had been repudiated. In Northzestern Oil \& Gas Co. v. Branine ${ }^{40}$ and Rich v. Doneghey, ${ }^{41}$ Brown v. Wilson was overruled. In these opinions the tenancy at will doctrine was declared to be erroneous.

In Texas, the Civil Court of Appeals in a number of decisions has held that the presence of a "surrender" clause in an oil and gas lease made it invalid for want of consideration, and from the language of these cases it may be inferred that they have adopted the notion that such a clause in a lease created a tenancy at will. ${ }^{42}$ In Guffey Petroleum Co. $v$. Oliver, ${ }^{43}$ the court expressly held that a tenancy at will was created and that the lessor might at any time cancel the lease on payment or tender to the lessor the value of the services performed on the land. The doctrine of this case was adopted by the Civil Court of Appeals in Owens v. Corsciana Petroleum Co., ${ }^{44}$ but this latter case was overruled by the Supreme Court of Texas, ${ }^{45}$ thus completing the repudiation in practically all jurisdictions of the erroneous notion that an oil and gas lease giving power to the lessee to terminate it, creates a tenancy at will and subject to termination at any time by the lessor.

The second theory upon which the validity of oil and gas leases containing optional drilling clauses have been attacked, that is, that such leases are unperformed optional contracts and void for lack of consideration, is directly traceable to two earlier but unsound theories respecting oil and gas leases. The first of these last mentioned theories is, that the

${ }^{40}$ (19i8) 7r Okla. I07, x75 Pac. 533, 3 A. L. R. 344

4 So, if it should be held that the grant here is of a freehold interest in the land, it is valid as such, having been executed with all the formalities necessary, under our statutes, for the conveyance of an freehold estate, and the instrument therefore does not create merely an estate at will. If, on the other hand, the view is taken that the grant is for a definite term, in the nature of an estate for years, the fact that it may be sooner terminated, at the option of the lessee, does not convert the grant from one in the nature of a tenancy for years into one in the nature of a tenancy at will. In either case, the above rule stated by Coke is not applicable. For these reasons we held in Northwestern Oil \& Gas Co. v. Bravind supra, that the presence of the surrender clause 'did not confer on the lessor the right to terminate the lease at will." "Rich v. Doneghey, supra note 3 , at p. 219, I77 Pac. 100.

¿ Natl O. \& P. L. Co. v. Teel (r902, Tex. Civ. App.) 67 S. W. 545; Roberts v. McFadden (xg03) 32 Tex. Civ. App. 47, 74 S. W. III; Emery v. League (Ig03) 31 Tex. Civ. App. 474, 72 S. W. 603; Hodges v. Brice (Ig03) 32 Tex. Civ. App. 358, 74 S. W. 590; Witherspoon v. Staley (I9I I, Tex. Civ. App.) I38 S. W. Ir9I; ibid. (1913) I56 S. W. 557. But see I59 S. W. XXIII where the Supreme Court refused writ of error on ground that the lease was forfeited and refused to commit itself on validity. Guffey Pet. Co. v. Oliver (I904, Tex. Civ. App.) 79 S. W. 884 .

is Loc. cit.

is (1914) I6g S. W. 200.

${ }^{4}$ Corsciana Pet. Co. v. Owerus, supra note $3 \mathrm{I}$. 
interest created by an oil and gas lease is executory until oil and gas are produced, and the second, that the prospective oil royalties and gas well rentals are the sole consideration moving from the lessee to the lessor for the privilege given by him to the lessee to explore for and produce oil and gas.

The doctrine that an oil and gas lease creates merely an executory or inchoate interest in the lessee until production had its origin in $M c N i s h$ v. Stone $e^{46}$ but the principle was restated in Venture Oil Co. v. Fretts ${ }^{47}$ and the latter case is generally credited with its origin. In the Fretts case, a senior lessee who had drilled a dry hole but had done nothing further for a period of seven years, brought an action of ejectment against a junior lessee. The defense was abandonment by the senior lessee. The court recalled the doctrine that, "a vested title cannot ordinarily be lost by abandonment in less time than that fixed by the statute of limitations unless there is satisfactory proof of an intention to abandon." The fact that the parties contemplated immediate development, coupled with the lessee's inaction for seven years, would seem to show that there was no lack of evidence of the lessee's intention to abandon the lease. The court, however, apparently not satisfied to place its decision on that ground, announced that oil and gas leases were an exception to the rule that vested interests could not be abandoned in a less period than that fixed by the statutes. Then instead of stating the reason and policy upon which such leases might well be excepted from the operation of such a rule, that is, the peculiar economic and physical facts of oil and gas, the court stated that they were an exception to it because: "The title is inchoate, and for purposes of exploration only, until oil is found. If it is not found no estate vests in the lessee, and his title, whatever it is, ends when the unsuccessful search is abandoned. If oil is found, then the right to produce becomes a vested right, and the lessee will be protected in exercising it in accordance with the terms and conditions of the contracts."

This statement of the Pennsylvania court has been widely quoted and paraphrased, ${ }^{48}$ with the natural result that oil and gas leases have

" (I879) found in footnote to Venture Oil Co. v. Fretts, supra note I.

"Sicpra note I.

4 Hooks v. Forst (1895) I55 Pa. 238, 30 Atl. 846; Chambers v. Smith (1897) 183 Pa. 122, 38 Atl. 522; Ahrens v. Chartiers Valley Gas Co. (1898) I88 Pa. 249, 4I Atl. 739; Colgan v. Forest Oil Co. (I899) I94 Pa. 234, 45 At1. I19; Wilson v. Phila. Co. (I904) 210 Pa. 484, 60 At1. I49; Burgan v. South Penn Oil Co. (1914) 243 Pa. r28, 89 At1. 823; State v. South Penu Oil Co. (1896) 42 W. Va. 80, 24 S. E. 688; Crazford v. Ritchey (1897) 43 W. Va. 252, 27 S. E. 220 ; Steelsmith v. Gartlan, supra note 6; Parish Fork Oil Co. v. Bridgewater Gas Co. (Ig02) $5 \mathrm{I}$ W. Va. 583, 42 S. E. 655; Eastern Oil Co. v. Coulehan (1909) 65 W. Va. 531, 64 S. E. 836; Garrett v. South Penn Oil Co. (I909) 66 W. Va. 587, 66 S. E. 744; Harris v. Michael (1910) 70 W. Va. 483, 76 S. E. 966; Musgrave v. Musgrave (1920) 86 W. Va. I19, I03 S. E. 302; Heal v. Niagara (I898) I50 Ind. 483, 50 N. E. 482 ; Ramage v. Wilson (1909 Ind. App.) 88 N. E. 862; Kokomo Nat. Gas Co. v. Matlock (1912) I77 Ind. 225, 97 N. E. 787; Brookshire Oil Co. v. Casmalia 
been looked upon as executory contracts. Space does not permit criticism of the doctrine here. It is enough, perhaps, to say that, viewing the oil and gas cases as a whole, the doctrine has proven to be a high sounding, but false and misleading statement, which has caused considerable confusion, particularly in the subject of the present inquiry. Proof of the incongruity of the doctrine is established by decisions to the effect that oil and gas leases may be abandoned after as well as before production, ${ }^{49}$ that the policy rules requiring certain formalities for the transfer of interests in land which must be complied with on the execution of the lease, ${ }^{50}$ that immediately upon the execution of the

(1909) I56 Calif. 21I, 103 Pac. 927; Dickey v. Coffeyville V. B. \& T. Co., supra note 31; Razlins v. Armel (I905) 70 Kan. 778, 79 Pac. 680; Foster v. Elk Fork O. \& G. Co., supra note 3; Huggins v. Daley, supra note 3; Fed. Oil Co. v. Western Oil Co., supra note 3I; Payne v. United States ('I92I, C. A. D. C.) 269 Fed. 87x; Emery v. League, supra note 42; Davis v. Texas Co. (I921, Tex. Civ. App.) 232 S. W. 549; Kolachny v. Galbreath (r910) 26 Okla. 972, IIo Pac. 902; Brennan v. Hunter (rgi3) 68 Okla. II2, I72 Pac. 49; Florence O. \& R. Co. v. Orman (I903) I9 Colo. App. 79, 73 Pac. 628; Conkling v. Krandisky (1908, 4th Dept.) I27 App. Div. 76r, 112 N. Y. Supp. I3.

${ }^{\circ}$ Marnett O. \& G. Co. v. Munsey (I92I, Tex. Civ. App.) 232 S. W. 867; Munsey v. Marnett O. \& G. Co. (I923, Tex.) 254 S. W. 3II; Eastern Oil Co. v. Coulehan (1909) 65 W. Va. 53I, 64 S. E. 836; Harris v. Michael (I912) 70 W. Va. 356, 73 S. E. 934 ; Sult v. Hochstetter Oil Co. (I908) 63 W. Va. 317, 6I S. E. 307; Buffalo Valley O. \& G. Co. v. Jones (1907) 75 Kan. 18, 88 Pac. 537 ; Heintz v. Shortt (I893) I49 Pa. 286, 28 At1. 228; Robinson v. Jacobs (I923, Tex.) 254 S. W. 309; Thomason v. Ham (1923, Tex.) 254 S. W. 316; Caruthers v. Leonard (I923, Tex. Comm. App.) 254 S. W. 779; Texas Co.v. Davis (I923, Tex.) 254 S. W. 304.

${ }^{50}$ Statute of Frauds: Heller $v$. Dailey (Ig02) 28 Ind. App. 555, 63 N. E. 490 ; Ramage v. Wilson (1906) 37 Ind. App. 532, 77 N. E. 368; Robinson v. Smalley (1918) I02 Kan. 842, I7I Pac. II55; White v. Green (1918) I03 Kan. 405, I73 Pac. 974; Beckett-Iseman Oil Co. v. Backer (1915) I65 Ky. 818, I78 S. W. I084; Prout v. Hoy Oil Co. (I9I4) 263 I11. 54, to5 N. E. 26; Kennedy v. Burns (I919) 84 W. Va. 701, Ior S. E. 156; DeHart v. Enright (I916, Sup. Ct.) 93 Misc. 213, r57 N. Y. Supp. 46; Mont. \& W. Oil Co. v. Gibson (I9Ir) I9 Wyo. I, II3 Pac. 784; Priddy v. Green (1920) 220 S. W. 243; Texas Co. v. Tankersley (I92I, Tex. Civ. App.) 229 S. W. 672; Canon v. Scott (Ig2r, Tex. Civ. App.) 230 S. W. ro42; Tupeker v. Deaner (1915) 46 Okla. 328, I48 Pac. 853; contra: Walla Walla O. G. \& P. L. Co. v. Vallentine (1918) 103 Wash. 359, 174 Pac. 980. Lease Amounts to Sale of Infant's Lands: Appeal of Stoughton (1878) 88 Pa. I98; Blakely v. Marshall (I896) I74 Pa. 425, 34 At1. 564; Marshall v. Mellon (I897) I79 Pa. 37I, 36 :At1. 20r; Jennings v. Blomfield (1901) I99 Pa. 638, 49 Atl. I35; McIntosh v. Ropp (I9I2) 233 Pa. 497, 82 Atl. 949; Wilson v. Youst (1897) 43 W. Va. 826, 28 S. E. 79; South Penn Oil Co. v. McIntyre (1898) 44 W. Va. 296, 28 S. E. 922; Haskell v. Sutton (1903) 53 W. Va. 206, 44 S. E. 533; but see Dulf v. Keaton (Igr2) 33 Okla. 92, r24 Pac. 291 ; 42 L. R. A. (N. s.) 472; Tibbens v. Clayton (I923, E. D. Okla.) 288 Fed. 393; Papoose Oil Co. v. Swindler (1923, Okla.) 22I Pac. 506. A Conveyance of LAND BY A Married Woman: Columbian Oil Co. v. Blake (1895) I3 Ind. App. 680, 42 N. E. 234; but see Heal v. Niagara Oil Co. (I898) x50 Ind. 483, 50 N. E. 482; and Kokomo Nat. O. \& G. Co. v. Matlock (IgI2) I77 Ind. 225, 97 N. E. 787 where the Fretts case was followed. An Alienation of Land WitHin the Meaning of Acts of Congress Removing Restrictions on the Alienation of 
lease the lessee will be protected in law and equity as against the lessor or third person who take or attempt to take the oil and gas by operations on the leased land, ${ }^{51}$ and finally, by many decisions which have expressly held that the lessee, immediately upon the execution of the lease, acquires a vested interest in the land for the purposes thereof, ${ }^{52}$ subject to be defeated by a breach of condition subsequent..$^{53}$

Ailotted Indian Lands: Eldred v. Okmulgee L. \& T. Co. (I908) 22 Okla. 742, 98 Pac. 929; Sharp v. Lancaster (I909) 23 Okla. 349, Ioo Pac. 578; Barnes v. Stonebreaker (Igog) 28 Okla. 75, II3 Pac. 903; Hoyt v. Fixico (I9I8) 7x Okla. 103, I75 Pac. 5I7; Parker v. Riley (1917, C. C. A. 8th) 243 Fed. 42; United States v. Noble (1914) 237 U. S. 74, 75 Sup. Ct. 532. A Conveyance of INTEREST IN Homestead: Gillespie v. Fulton O. \& G. Co. (1908) 236 I11. I88, 86 N. E. 2I9; Bruner v. Hicks (I907) 230 Ill. 536, 82 N. E. 888; Poe v. Ulrey (Ig08) 233 IIl. 56, 86 N. E. 84; Franklin Land Co. v. Wea Gas Co. (1890) 43 Kan. 518, 23 Pac. 630, ibid. (1895) 54 Kan. 533, 38 Pac. 790; Palmer O. \& G. Co. v. Parish (I900) 6r Kan. 330, 59 Pac. 640; Thompson v. Milliken (rgr4) 93 Kan. 72, r43 Pac. 430 ; ibid. (I918) I02 Kan. 717, I72 Pac. 534; Peterson v. Skidmore (I921, Kan.) I95 Pac. 600; Carter Oil Co. v. Popp (I9I8, Okla.) I74 Pac. 747; Francen v. Okla. Oil Co. (1920, Okla) I94 Pac. I93; Miles v. Jerry (I923, Ark.) 250 S. W. 34; South Oil Co. v. Colquit (1902) 28 Tex. Civ. App. 292, 69 S. W. I69; Maynard v. Gilliam (1920, Tex. Civ. App.) 225 S. W. 818; McIntire v. Thomason (1919, Tex. Civ. App.) 210 S. W. 563; Davis v. Burkholder (1920, Tex. Civ. App.) 218 S. W. Iror; Texas Co. v. Keeter (I920, Tex. Civ. App.) $2 x 9$ S. W. 52I; Fagan v. Texas Co. (1920, Tex. Civ. App.) 220 S. 'W. 346; Johnson v. Russell (1920, Tex. Civ. App.) 220 S. W. 352; Hamilton Oil Dev. Co. v. Sullivan (1920, Tex. Civ. App.) 220 S. W. 116; Richmond 3 . Hog Creek Oil Co. (1921, Tex. Civ. App.) 229 S. W. 563; Carey v. Tex.-Pac. C. \& O. Co. (I921, Tex. Civ. App.) 237 S. W. 309; Gary v. McKinney (I922, Tex. Civ. App.) 239 S. W. 238; Bell v. Crabb (I922, Tex. Civ. App.) 244 S. W. 37I.

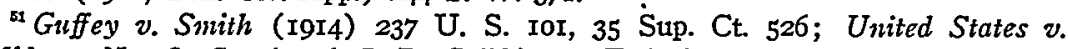
Midway No. O. Co. (I9r6, S. D. Calif.) 232 Fed. 6r9; Isom v. Rex Crude Oil Co. (1905) I47 Calif. 659, 82 Pac. 319; Kahle v. Crowen Oil Co. (1913) I8o Ind. I3I, 100 N. E. 68ז; Campbell v. Smith (I9I3) 180 Ind. 159, IOI N. E. 89; Bryson v. Crown Oil Co. (1916) I85.Ind. 156, I12 N. E. I; New Domain O. \& G. Co. v. McKinney (1920) I88 Ky. 183, 221 S. W. 245; Barnes v. Winona Oil Co. (1921) 83 Okla. 253, 200 Pac. 985; Zelma Oil Co. v. Nemo Oil Co. (I92I) 84 Okla. 2I7, 203 Pac. 203; Duffield v. Rosenweig (I89I) I49 Pa. 520, 23 Atl. 4; Crawford v. Forest Oil Co. (Ig04) $208 \mathrm{~Pa}$ 5, 57 Atl. 47; Bender $v$ Brooks (I9I3) I03 Tex. 329, I27 S. W. I68; Bettman v. Harness, supra note $3 ; 36$ L. R. A. 566; Haskell v. Sutton (1903) 53 W. Va. 206, 44 S. E. 533; Pittsburg Gas Co. v. Pentress Gas Co. (1919, W. Va.) I00 S. E. 296, 7 A. L. R. 901.

${ }^{\text {a }}$ Brumer v. Hicks (I907) 230 III. 536, 82 N. E. 889; Watford O. \& G. Co. v. Shipnnan (r908) 233 I11. 9, 84 N. E. 53I; Poe v. Ulrey, supra note 50; Ulrey v. Keith (1908) 237 Ill. 284, 86 N. E. 696; Danghtee v. Ohio Oil Co. (I9I4) 263 II1. 518, 105 N. E. 308; People v. Bell (I908) 237 I11. 332, 86 N. E. 593; Guffey v. Smith, supra note 5I; Breman v. Hunter (I9I8) 68 Okla. II2, I72 Pac. 49; Northzestern O. \& G. Co. v. Branine (I918) 7I Okla. I67, I75 Pac. 533; Rich v. Doneghey (I9I8) 7I Okla. 204, I77 Pac. 86; Lindley v. Raydure, supra note 3I; Lyon v. Union G. \& O. Co. (r921, E. D. Ky.) 274 Fed. 957; McCullough v. Smith (1917, C. C. A. 8th) 243 Fed. 823; Smith v. McCullough (I922, C. C. A. 8th) 285 Fed. 698; Ewert v. Robinson (1923, C. C. A. 8th) 289 Fed. 740; Shaffer v. Marks, supra note 31 .

ss Texas Co. v. Daugherty (I9I5, Tex.) I76 C. W. 7I7; Stephens County v. Mid Kansas Oil Co. (I923, Tex.) 254 S. W. 290; Munsey v. Marnett O. \& G. Co. 
The theory that the payment of oil and gas royalties constituted the sole and moving consideration from the lessee to the lessor for the grant by the lessor of the privilege to operate the land for oil and gas, had its origin in the earlier stages of the industry. In the earlier leases, as stated above, the cash consideration was usually nominal, the lessee covenanted to immediately develop the premises to success or abandonment and pay stipulated royalties or suffer forfeiture of his lease. But with the introduction of the "drill or pay" or "unless" type of lease and the "surrender" clause, the lessee no longer covenanted absolutely to develop the land immediately, but promised to drill, pay a delay rental, surrender it, or allow it to terminate by failure to pay. Under such a type of lease it cannot be said that the prospective royalties are the only consideration inducing the lessor to execute the lease, and this is particularly true where a cash bonus is paid based on a prospective value of the land for oil and gas purposes. But despite this change in type of leases the statement of the earlier cases that royalties were the only consideration has persisted in later decisions. ${ }^{54}$

The fusion of these two ideas, that is, that an oil and gas lease is merely an executory contract creating no present interest in the land, and that the sole consideration moving from the lessee to the lessor is the promise to pay royalties, to reach the erroneous conclusion that where the lease contains an optional drilling clause coupled with a "surrender" clause that the lease is an unperformed contract, optional as to one party and therefore optional as to both, is clearly traceable to a number of cases. ${ }^{55}$ Had the courts not reasoned from these two false premises, they would certainly have reached the conclusion that an oil

(1923, Tex.) 254 S. W. 3II; Robinson v. Jacobs (1923, Tex.) 254 S. W. 309; Texas Co. v. Davis (r923, Tex.) 254 S. W. 304; Thomason v. Ham (I923, Tex.) 254 S. W. 316; Thomason v. McIntire (I923, Tex.) 254 S. W. 3I5; Caruthers v. Leonard (I923, Tex. Comm. App.) 254 S. W. 779.

${ }^{34}$ Huggins v. Daley, supra note 3 ; Venture Oil Co. v. Fretts, supra note I; and also the following cases cited supra in note 3: Steelsmith v. Gartlan, Foster $v$. Elk Fork O. \& G. Co., Gadbury v. Ohio \& Ind. Gas Co., Coztan v. Radford Iron Co., Knight v. Ind. C. \& I. Co., Fed. Oil Co. v. Western Oil Co., Witherspoon v. Staley, Smith v. Guffey. Ozens v. Corsciana Pet. Co., Gt. Western Oil Co. v. Carpenter, Long v. Sun Co., Jennings Hayzwood Synd. v. Houssiere-Latreille Oil Co., Murray v. Barnhart. Dill v. Fraze. Ohio Oil Co. v. Detamore, Mansfield Gas Co. v. Alexander, Berry v. Frisbie, Bay St. Pet. Co. v. Penn Lubricating Co., Flanagan v. Marsh.

${ }^{3}$ Cowan v. Radford Iron Co., supra note 3 ; Steelsmith v. Gartlan, supra note 3; Huggins v. Daley, supra note 3; Reese v. Zinn (I900, C. C. D. W. Va.) ro3 Fed. 97; Eclipse Oil Co. v. South Perm Oil Co., supra note 9; Fed. Oil Co. v. Western Oil Co., supra note 3; Trees v. Eclipse Oil Co., supra note 25; National O. \& P. L. Co. v. Teel (I902, Tex. Civ. App.) 67 S. W. 545 ; Hodges v. Brice (I903) 32 Tex. Civ. App. 358, 74 S. W. 590; Roberts v. McFadden (Ig03) 32 Tex. Civ. App. 47, 74 S. W. III; Emery v. League, supra note 42; Pet. Co. v. Oliver (I904, Tex. Civ. App.) 79 S. W. 884; Witherspoon v. Staley, supra note 54; Ozens v. Corsciana Pet. Co., supra note 3; Brozen v. Wilson (1916) 58 Okla. 392, I60 Pac. 94. 
and gas lease is a conveyance of a presently vested interest in land, creating an estate for years, on limitations or condition subsequent, and most of the litigation as to whether or not as a contract such lease is based upon sufficient consideration would have been avoided. But they considered it as a contract, and it is on this basis that most of the cases, whether they have held the leases good or bad, have been decided. Therefore, in the discussion of this phase of the subject the leases will be considered from the standpoint of their validity as contracts without regard to whether or not they are conveyances of interests in land. For the purposes of clarity, the discussion will be based upon a number of hypothetical cases.

I. Suppose an oil and gas lease for a long certain term of years does not contain a recital or acknowledgment of the receipt of. an initial cash consideration, but purports to be made in the consideration of a promise by the lessee to pay royalties, if the lessee deems it advisable within a certain definite period to explore the land and produce oil and gas therefrom. There is no unconditional promise to drill or to produce oil and gas if found. In such a case the Supreme Court of Tennessee properly held that the lease was void for the reason that there was no absolute promise on the part of the lessee which imposed any legal duty upon him to serve as a consideration for the promise of the lessor. ${ }^{58}$

2. Suppose the lease is without a recital or acknowledgment of receipt of an initial cash consideration, but purports to be made in consideration of certain covenants on the part of the lessee, and the lessee covenants to pay royalties, to drill a well on the premises within a specified time, or in lieu thereof pay a certain rental ("drill or pay" clause), and in addition the lessee is given power to surrender the lease at any time, without being required to pay an additional consideration as a condition precedent to the exercise of the power. In a West Virginia case $^{57}$ such a lease has been held void. The reason assigned for this holding was that because of the presence of the surrender clause the lessee was under no binding duty to do any act of benefit to the lessor which served as consideration for the lessee's privilege to drill on the land. This view seems sound, although a contrary view has been asserted by some authorities. In a dissenting opinion to the West Virginia case, one judge took the view ${ }^{58}$ that since the lessor

"Pet. Co. v. Coal, Coke \& Mfg. Co., supra note r.

${ }^{57}$ Eclipse Oil Co.v. South Pens Oil Co., supra note 9; Trees v. Eclipse Oil Co., supra note 25.

"What consideration is there? The owner wants his land developed. He cannot do so himself. By the contract he has a chance, a fair probability, of the other man's doing it for him: and if not that, the chance, the probability, of getting an agreed rental. He made the lease for this consideration. The consideration though not concurrent or executed is executory. The one had the chance of benefit. That is a consideration binding him. The other ran the risk of detriment. That makes the lease good in his favor against the other." 
wanted his land developed and could not do it himself, that the probability of the lessee's performance, that is, drilling or paying, although not bound to do so, conferred a benefit upon the lessor, and furnished sufficient consideration to support the contract. But according to the orthodox theory of consideration the beneficial liability thus created in the lessor does not seem to be a sufficient consideration to support the contract.

2a. If, however, in the type of lease under consideration, there be added a clause placing a duty upon the lessee to pay a sum of money, nominal or substantial, as a condition precedent to the exercise of the power of surrender, the lease is not without consideration to support it. The lessee has made an absolute promise to do one of three things. He must drill, pay delay rental, or pay a sum of money to the lessor to free himself from his other duty. ${ }^{69}$

2b. If the surrender clause in such a lease contains a provision that as a condition precedent to its exercise the lessee must pay all accrued rentals, and this is the only condition precedent, such a clause does not provide a valid consideration for the contract from its inception, for the reason that the lessee may surrender before rent has accrued and thus escape all obligations by such act. If, however, the lessor has not elected to withdraw his own promise until rent has accrued, it seems only logical that he could not afterwards do so, because under the "drill or pay" lease the lessee is then bound to pay the rent under any circumstances.

3. Suppose the lease does not recite or acknowledge the payment of an initial cash consideration, but contains a covenant to pay royalties and to drill within a specified time, but with a provision that if the lessee does not drill within the time mentioned the lease is to terminate, unless the lessee pays certain sums periodically in advance to keep the lease alive ("unless" drilling clause). Such a lease does not place a binding duty upon the lessee to do anything. The contract is in effect the same as a "drill or pay" lease coupled with a simple "surrender" clause. The lessee is not bound to drill or to pay. If he does not drill or pay the lease ends by its own terms. Some courts, however, have recently expressed the opinion that a promise to drill in an "unless" lease is sufficient consideration to support it..$^{60}$

3a. The addition of a "surrender" clause, even though such clause requires the lessee to pay a sum of money or accrued rentals as a con-

Brannon, J. dissenting, Eclipse Oil Co. v. South Penn Oil Co., supra note 9; see also McCaskey v. Schrock (1920, Tex. Civ. App.) 225 S. W. 4I8, where it was held that a promise to drill in an "unless" lease was sufficient to support the contract although the recited consideration was not paid. This opinion overlooks the fact that under the "unless" drilling clause the lessee was under no duty to drill or pay. See also McCaskey v. McCall (1920, Tex. Civ. App.) $226 \mathrm{~S}$. W. 432; Heard v. Pratt (I924, Tex. Civ. App.) 257 S. W. 660; Marnett O. \& G. .. Co. v. Munsey (Ig21, Tex. Civ. App.) 232 S. W. 867.

${ }^{*}$ Rich v. Doneghey, supra note 3.

${ }^{\infty}$ McCaskey v. Schrock, supra note 58; McCaskey v. McCall, supra note 58. 
dition precedent to the exercise of the power to surrender, does not create any different situation, for the reason that the lessee has not made a promise to pay to escape which the instrumentality of the "surrender" clause is needed, and he may escape his promise to drill by simply not performing it and allowing the lease to terminate. ${ }^{61}$

4. Suppose the lease contains a recital of an initial consideration of one dollar, covenants on part of the lessee to drill within a certain time but if he does not the lease will be void unless the lessee pay a stipulated sum in advance for its further continuance. Although the lessee is not bound absolutely to drill or to pay, the one dollar consideration recited supports the lease as a whole. This type of lease has not often been questioned in the courts, but has practically always been upheld as supported by valid consideration when questioned even though there is no promise to drill. ${ }^{62}$

4a. But where there is added to this lease a power in the lessee to surrender, with or without payment of an additional consideration, nominal or substantial, it has been attacked. These courts have not realized, however, that the addition of the surrender clause has not in any respect relieved the lessee of any duty that he has had, ${ }^{63}$ but other courts have supported such contracts upon the ground that the initial consideration supports all parts of the lease including the surrender clause. ${ }^{64}$ The error of the former view will be discussed now.

5. Suppose that a lease contains a recital or acknowledgment of the receipt of an initial cash consideration of one dollar or other nominal sum, covenants on the part of the lessee to pay royalties, to drill within a certain time or pay delay rentals (drill or pay clause) with an added power to surrender, with or without paying an additional nominal or serious consideration as a condition precedent to the exercise of the power. It is with respect to this type of lease that most of the litigation questioning the validity of oil and gas leases for want of consideration has occurred. And it is here that some of the courts have been influenced by the notion that oil and gas leases are purely executory contracts, the promise of the lessee to develop the land and pay oil or

"In Fed. Oil Co. v. Western Oil Co., supra note 3, the lease was objected to because of the surrender clause, although it might have well been declared invalid for the same reason, because of the "tunless" drilling clause.

"South Penn Oil Co. v. Snodgrass (I9I2) $7 \mathrm{r}$ W. Va. $438,76 \mathrm{~S}$. E. 96r, 43 L. R. A. (N. S.) 848 ; Brown v. Fozoler (1902) 65 Ohio St. 507,63 N. E. 76 ; Allegheny Oil Co. v. Sivyder (1900, C. C. A. 6th) 106 Fed. $764 ;$ Miller v. Union Gas Co. (I924, C. C. A. 6th) 295 Fed. 27 ; Leeper v. Neely, supra note 3I; Brunson v. Carter Oil Co. (1919, E. D. Okla.) 259 Fed. 656; Lone Star Gas Co. v. $M c C u l l o n g h$ (I920, Tex. Civ. App.) $220 \mathrm{~S}$. W. III4; Hopkins v. Zeigler (IgI9, C. C. A. 6th) 259 Fed. 43; Marnett O. \& G. Co. v. Munsey (I921, Tex. Civ. App.) 232 S. W. 869; Garfield Oil Co. v. Champlin (Ig20, Okla.) 169 Pac. 5I4.

"Fed. Oil Co. v Western Oil Co., supra note 3.

"See cases cited in note 55 . The question of the validity of the "unless lease" where dependent upon nominal consideration is discussed under supposition case five infra. 
gas royalties being the total consideration moving from the lessee to the lessor. And it is on this basis that they have held that since the surrender clause permits the lessee to escape this duty, the contract is void. The courts have two expressions through which they voice their opinion that such an oil and gas lease is invalid and may be cancelled at the will of the lessor. One, "that contracts, unperformed, optional as to one of the parties, are optional as to both," and the other, "that the contract is unilateral, and void because lacking in mutuality." The first statement has reference only to contracts depending entirely for their validity on mutual promises, ${ }^{65}$ and to be applicable to the contracts here involved the initial cash consideration must be entirely disregarded. The second statement is misleading. Unilateral contracts are not necessarily void, or void because lacking in mutuality of obligation. The term unilateral has in the law of contract been used to describe two entirely different situations. The correct use of the term is to describe a contract where one party has performed his part of the consideration and there is an outstanding promise to perform on the part of one party only. In such contracts there is no mutuality of outstanding obligation. But the term unilateral is sometimes ised to indicate a situation where one party has made a promise for which no sufficient consideration is given. Such a situation is really not a contract at all, for the simple reason that it does not have sufficient consideration to support it. ${ }^{66}$ It is believed that it is this second use of the term unilateral that the courts have had in mind when they speak of oil and gas leases as unilateral contracts. The lack of mutuality referred to by them is a lack of mutuality of consideration and not mutuality of obligation. If the premise upon which these courts proceed is sound, that is, that prospective royalties are the sole and only consideration for the promise of the lessor, then certainly their second ground, that is, that the contract is unilateral and void for want of mutuality, using the terms as above indicated, is sound. But this, as well as the first reason given, is based upon the assumption that the recited or acknowledged nominal consideration is not sufficient to support the contract.

"It is," says Professor Williston, "ar "an 'elementary principle that the law will not enter into an inquiry as to the adequacy of the consideration." ${ }^{\text {'8 }}$ This rule is almost as old as the law of consideration itself. Therefore, anything which fulfills the requirements of consideration whatever may be the comparative value of the consideration, and of the thing promised."

Relying upon this principle a great majority of the courts in the oil and gas producing states have held that one dollar is a sufficient con-

\footnotetext{
os I Williston, Contracts (I920) sec. I40; 6 R. C. L. 686; I3 C. J. 336; Rich v. Doneghey, supra note 3 .

${ }^{80} x$ Williston, op. cit. sec. 13.

${ }^{e 7}$ I Williston, op. cit. sec. II5.

* Byles, J. in Westlake v. Adams (1858, C. P.) 5 C. B. (N. s.) 248, 265, I4I Eng. Rep. 99, 106; 6 R. C. L. 678; 13 C. J. 365; Rich v. Doneghey, supra note 3.
} 
sideration to support an oil and gas lease in which there is no binding duty on the lessee to drill or to pay rental. And they so hold, whether they view such a lease as a valid option to acquire an interest in land or as a contract partially executed by the payment of the initial consideration. The presence of a "surrender" clause, whether with or without an independent consideration to support it, is immaterial under such a view, for the initial consideration supports the whole contract. ${ }^{89}$

- In some cases, however, the rule that consideration need not be adequate has been ignored with the result that the lease has been looked upon as an executory contract, and because of the presence of the "surrender" clause, held void for want of consideration. ${ }^{70}$ This erroneous view, as heretofore suggested, is directly traceable to the influence

${ }^{\infty}$ Lovett v. Eastern Oil Co. (I9II) 68 W. Va. 667, 70 S. E. 707, Ann. Cas. I912B, 360, note; Lowther Oil Co. v. Guffey (I903) 52 W. Va. 88, 43 S. E. IoI; Pyle v. Henderson (I909) 65 W. Va. 39, 63 S. E. 762; South Pem Oil Co. v. Snodgrass, supra note 62; Cent. Ohio Nat. G. \& F. Co. v. Eckert (I904) 70 Ohio St. 127, 7r N. E. 28r ; Brown v. Fowler' (Igar) 65 Ohio St. 507, 63 N. E. 76; Poe v. Ulrey (1908) 233 Ill. 56, 84 N. E. 46; Watford O. \& G: Co. v. Shipman (1908) 233 Ill. 9, 84 N. E. 53; Pittsburg V. P. \& B. Co. v. Bailey, supra note 3I; Gadbury v. Ohio \& lnd. Gas Co. (1903) x6a Ind. 9, 67 N. E. 259; Dill v. Fraze (I907) 169 Ind. 53, 79 N. E. 97x; Rechard v. Cozvley, supra note 31; Gillespie v. Fulton Oil Co. (Ig08) 236 I11. x88, 86 N. E. 219; Brezester v. Lanyon Zinc Co., supra note 52; Allegheny Oil Co. v. Snyder, supra note 62; Miller v. Union Gas Marks, supra note 3I; Raydure v. Lindley, supra note 3I; McCullongh v. Smith, supra note 52; Allegheny Oil Co. v. Snyder supra note 62; Miller v. Union Gas Co., supra note 62; Leeper v. Neely, supra note 3I; Brunson v. Carter Oil Co., supra note 52; Allegheny Oil Co. v. Snyder, supra note 62; Miller v. Union Gas Okla.) I76 Pac. 912; Ardizonne v. Archer (1919, Okla.) I77 Pac. 554; Gcrfield Oil Co. v. Champlin (1920, Okla.) I89 Pac. 514; Southwestern O. \& G. Co. v. McDaniel (I9I8, Okla.) I75 Pac. 920; Nat. O. \& P. L. v. Teel, supra note 3 ; Witherspoon v. Staley (I913, Tex.) 159 S. W. XXIII (without opinion); Gt. Western Oil Co. v. Carpenter (1906) 43 Tex. Civ. App. 229, 95 S. W. 57 ; Corsciana Pet. Co. v. Ozens, supra note $3 \mathrm{I}$; Pierce-Fordyce Oil Assoc. $v$. Woodrun (1916, Tex. Civ. App.) I88 S. W. 245; Richmond v. Hog Creek Oil Co. (1920, Tex. Civ. App.) 229 S. W. 563; Hitson v. Gilman (1920, Tex. Civ. App.) 220 S. W. I40; Johnson v. Russel (1920, Tex. Civ. App.) 220 S. W. 352; Bost v. Biggers Bros. (1920, Tex. Civ. App.) 222 S. W. Iroz; Leath v. Humble O. \& Ref. Co. (1920, Tex. Civ. App.) 223 S. W. ro22; McCaskey v. Schrock, supra note 58; Lone Star Gas Co. v. McCullough (1920, Tex. Civ. App.) 220 S. W. III4; Nolan v. Young (1920, Tex. Civ. App.) 220 S. W. I54; McKay v. Talley (1920; Tex. Civ. App.) 220 S. W. I67; McKay v. Lucas (1920, Tex. Civ. App.) 220 S. W. 172; McKay v. Kilcrease ((1920, Tex. Civ. App.) 220 S. W. I77; Emde v. Johnson (I9r9, Tex. Civ. App.) 214 S. W. 575; McCaskey v. McCall, supra note 58; Stephenson v. Stitz (I92I, Tex. Civ. App.) 235 S. W. 27I; Dunaway v. Galbraith (r9I9) I39 Ark 580, 214 S. W. 33; Lazerence v. Mahoney (I920) I45 Ark. 310, 225 S. W. 340; Rogers v. Magnolia Oil Co., supra note 3r; Dorman Farms Co. v. Stewart (1923, Ark) 247 S. W. 778; Grooms v. Minton, siepra note 3 I.

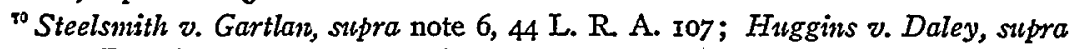
note 3; Fed. Oil Co. v. Western Oil Co., supra note 3; Natll O. \&. P. L. Co. v. Teel, supra note 42; Hodges v. Brice (1903) 32 Tex. Civ. App. 358, 74 S. W. 590; Roberts v. McFadden, supra note 42; Emery v. League, supra note 42; Pet. Co. v. Oliver (I904, Tex. Civ. App.) 79 S. W. 884; Witherspoon v. Staley, supra 
of the doctrine of the Venture Oil Co. v. Fretts ${ }^{71}$ and to the statement. in early cases that the promise of the lessee to pay rents and royalties is the sole consideration moving from him. This minority view had its beginnings in West Virginia state and federal casses. ${ }^{72}$ It was furthered by Federal Oil Co. v. Western Oil Co., ${ }^{73}$ and National Oil Pipe Line Co. v. Teel. ${ }^{74}$ In the first. of these cases the action was brought by the lessee to enforce a lease which recited a consideration of one dollar, contained an "unless" drilling clause and a surrender clause. The court refused to enforce the lease, among other grounds, because the "consideration would be so trifling, compared with the value of the leasehold interest as to shock the moral sense," although the court admitted that such a lease might be valid in law and not subject to cancellation in equity at the suit of the lessor. Although this case was later overruled by the Supreme Court, $7^{75}$ it had considerable influence with the Texas and Oklahoma courts. ${ }^{76}$

In the Teel case, the Texas Court of Civil Appeals, in a suit by the lessor against a bona fide assignee for value. cancelled a lease for fraud which recited a one dollar consideration and contained an "unless" drilling clause. This was done on the ground that the contract did not create an interest in land, but was merely an option to procure one, because the real consideration was the development of the property, for which no definite time was fixed in the lease. Although the Supreme Court of Texas affirmed the decision on the ground of fraud, it took pains to state that it considered the recited consideration sufficient to support the option. ${ }^{77}$ Despite this statement of the Supreme Court, and later statements to the same effect, ${ }^{78}$ several decisions in the Texas Court of Civil Appeals, relying upon the first opinion in the Teel case, supra, Federal Oil Co. v. Western Oil Co., supra, and the early West Virginia cases above mentioned, have held that a nominal consideration is not sufficient to support an oil and gas lease where the lessee is not

note 42; Owens v. Corsciana Pet. Co. (1914, Tex. Civ. App.) 169 S. W. 200; Brozen v. Wilson (1916) 58 Okla. 392, 160 Pac. 94; Heard!v..Pratt (1924, Tex. Civ. App.) 257 S. W. 660 .

${ }^{71}$ Stupra note 47.

${ }^{72}$ See cases cited supra note 70.

${ }^{73}$ Sipra note 63.

${ }^{74}$ (1902, Tex Civ. App.) 67 S. W. 545.

${ }^{75}$ Guffey v. Smith, supra note $5 \mathrm{I}$.

${ }^{7}$ See Texas and Oklahoma cases cited supra in note 70.

7 "Each of the contracts in this case purports upon its face to have been executed in consideration of the payment of one dollar; and, though the plaintiff below pleaded that no consideration was paid, there was no evidence that the recital as to the consideration in the contracts was not true. Whether the recital of ' $\$ \mathrm{I}$ '-commonly called a nominal consideration,-is sufficient to support the contracts, we need not discuss, though there is very high authority for holding that such recital is sufficient for the purpose." Nat'l O. \& P. L. Co. v. Teel (I902) 95 Tex. 586, 68 S. W. 979.

${ }^{78}$ See also the statement made by the Supreme Court of Texas, Witherspoon $v$. Staley, supra note 69 , in refusing a writ of error to review a decision of the Civil Court of Appeals. 
bound to drill or pay. ${ }^{79}$ The last of these cases, Owens v. Corsciana Petroleumi Co., ${ }^{80}$ was appealed to the Supreme Court and the question was definitely settled in favor of the validity of such leases. ${ }^{81}$

The Oklahoma court in a number of cases $^{82}$ refused specific performance of leases made on a nominal consideration which contained an "unless" drilling clause or a "surrender" clause on the principles of Federal Oil Co. v. Western Oil Co. But it was not until the decision of Brozen $v$. Wilson ${ }^{\mathrm{s3}}$ that these principles were invoked to permit the lessee to cancel the lease. In that case it was held that the . initial consideration supported the lease for the exploratory period only, and thereafter, if the lessee had not developed the land, the lease was voidable at the option of the lessor because without consideration to support it. This decision was, however, overruled by Northwestern Oil \& Gas Co. v. Branine ${ }^{84}$ and Rich v. Doneghey ${ }^{85}$ where it was held that one dollar initial consideration supports the entire lease.

There may be some doubt as to the exact attitude of the Kentucky court on the question under discussion, although in a recent federal case in that jurisdiction wherein he was bound by the rule of the state courts, Cochran, J., after an exhaustive review of the cases, held that a consideration of one dollar was sufficient to support a lease containing a "drill or pay" clause and a "surrender" clause. ${ }^{86}$

In Louisiana, where the code requires that consideration must be "serious" and the doctrine of the common law that consideration need not be adequate is not in force, it has been held in several cases, that a lease supported only by a nominal consideration is invalid. ${ }^{87}$ If the initial consideration prove inadequate, the lease may be held valid, although it contain a "surrender" clause, if as a condition precedent

"See Texas cases cited supra in note 70.

${ }^{80}$ Supra note 3.

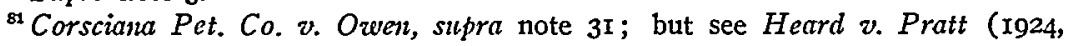
Tex. Civ. App.) 257 S. W. 660, where the court said, "The nominal consideration, of course, was inadequate, but that was not the sole and real consideration."

"Kolachny v. Galbreath, supra note 48; Superior O. \& G. Co. v. Mehlin (1910) 25 Okla. 809, 108 Pac. 545; Hill O. \& G. Co. v. White (rg16) 53 Okla. 748, I57 Pac. 710; Melton v. Cherokee O. \& G. Co. (I9I7) 67 Okla. 247, I70 Pac. 69x; Lima O. \& G. Co. v. Pritchard (1923, Okla.) 218 Pac. 863.

${ }^{83}$ Supra note 70 .

84 (1918) 7r Okla. 107, I75 Pac. 533.

${ }^{85}$ Supra note 3.

${ }^{s s}$ Raydure v. Lindley, supra note $3 \mathrm{I} ;$ Montarch O. \& G. Co. v. Richardson (1907) 124 Ky. 602, 99 S. W. 668; Berry च. Frisbie (1905) 120 Ky. 337, 86 S. W. 558 ; Soaper v. Kivrg (I915) 167 Ky. I2I, I80 S. W. 46. See also Leeper v. Neely, supra note 3I.

${ }^{87}$ Murray v. Barnhart (1906) I17 La. 1023, 42 So. 489 ; Houssiere-Latreille Oil Co. v. Jennings-Heyzood Synd. (1905) II5 La. 107, 38 So. 932 (see note 3 on rehearing); Gray v. Spring (I9II) I29 La. 345, 56 So. 305; Goodson v. Vivian Oil Co. (Igr2) r29 La. 95I, 57 So. 280; Long v. Sun Co., supra note 3; Cadeo O. \& $M$, Co. v. Producer's Oil Co. (I914) I34 La. 70I, 64 So. 648; Sannders v. Busch Everett \& Co. (I916) I38 La. I54, 71 So. 153; Bristow v. Christine O. \& G. Co. (1916) I39 La. Iого, 72 So. 718; Leonard v. Busch Everett \& Co. (I9I6) 
to the exercise of the power to surrender the lessee must pay a "serious" consideration, or if there is any other binding executory or executed consideration to support it. ${ }^{88}$

Although it seems settled law in all jurisdictions except Louisiana that one dollar is sufficient consideration to support an oil and gas lease, the validity of all leases made upon such recited consideration is not necessarily established. The recital of a nominal consideration being merely a statement of past fact, parol evidence -may be admitted to show the recited fact untrue, or that the consideration. has not been paid. If, however, the consideration stated is in the form of a promise, parol evidence is inadmissible. ${ }^{39}$ In an early case Story, J., said: "The guarantor acknowledged the receipt of one dollar, and is now estopped to deny it. If she had not received it, she would now be entitled to recover."'90 The error of this is in treating the acknowledgment of the receipt, although the money was not paid, as a promise to pay, thus giving the recital of consideration the characteristics of a promise and barring all parol testimony as to the truth by making the parol evidence rule applicable. To what extent this statement has misled the courts in refusing evidence offered to prove that a recited consideration in an oil and gas lease was not in fact paid or ever intended to be paid can only be surmised. In some oil and gas cases such evidence has been refused, ${ }^{91}$ in others it has been admitted, ${ }^{92}$ and still others say that it makes no difference whether the nominal consideration is paid or not for the recital amounts to a promise to pay which supports the lease. ${ }^{93}$ This last holding is in direct reliance upon the authority of Justice Story's statement above quoted.

Since in practically all jurisdictions a nominal consideration is suffi-

I39 La. I099, 72 So. 749; Raines v. Dunuson (I919) I45 La. 525, 82 So. 690; Garrett v. Schreveport L. \& M. Co. (1922) 151 La. 983, 92 So. 565; Wilder v. Norman (I920) I47 La. 4r3, 85 So. 59; Wilder v. Jackson (I922) 150 La. 864, 91 So. 245; Miller v. Oden (I921) I49 La. 77x, 90 So. I67.

${ }^{\$}$ Wilkins v: Nelson (1924) I55 La. 807, 99 So. 607; Fomby v. Columbia Connty Dev. Co. (I924) 155 La 705, 99 So. 537; Glassel v. Richardson Oil Co. (I922) I50 La. 999, 9I So. 43I; Houssiere-Latreille Oil Co. v. Jennings-Heywood Synd., supra note 87; Saunders v. Busch Everett \& Co., supra note 87; Hudspeth v. Producer's Oil Co. (I9I4) I34 La. IOI3, 64 So. 89I; McClendon v. Busch Everett Oil Co. (1916) I38 La. 722, 70 So. 781; Cochranv. Gulf Ref. Co. (1916) 139 La. I010, 72 So. 718.

${ }^{\approx}$ I Williston, op. cit., supra note 66, sec. II5a, Ir5b; 4 Wigmore', Evidence (I904) sec. 2433 ; Io R. C. I. I044.

${ }^{90}$ Lawerence v. McCalmont (I844, U. S.) 2 How. 426; Davis v. Wells (I88I) I04 U. S. I59.

${ }^{91}$ See Raydure v. Lindley, supra note 3I; Stephenson v. Stitz (rg2I, Tex. Civ. App.) 235 S. W. 271 ; Nolan v. Young (1920, Tex. Civ. App.) 220 S. W. I54.

${ }^{m}$ Hitson v. Gilman (1920, Tex. Civ. App.) 220 S. W. I40; Varnes v. Dean (x920, Tex. Civ. App.) 228 S. W. Ior7; McCaskey v. Schrock, supra note 58.

${ }^{{ }^{3} M c K a y}$ v. Talley, supra note 69 ; Bost v. Biggers Bros., supra note 69 ; Masterson v. Amarillo Oil Co. (I923, Tex. Civ. App.) 253 S. W. 908; Silverman v. Emerson (I924, Tex. Civ. App.) 257 S. W. 6x2. These cases rely upon the statement found in I3 C. J. 367 where Story's statement is paraphrased. 
cient to support an oil and gas lease regardless of the type of drilling clause, or the presence of a surrender clause, it is only necessary to state that leases are held valid when made upon payment of a substantial cash bonus. ${ }^{94}$ In Louisiana, however, the court must always be satisfied that the cash bonus is adequate. ${ }^{95}$ It must likewise not be overlooked, in all the situations heretofore discussed, that if there is no consideration in the form of initial cash payment, nominal or substantial, or any binding promise to drill or pay rentals because of the "surrender" clause or "unless" drilling clause, or if the cash consideration has not been paid or intended to be paid, a majority of the courts hold that the lessor cannot cancel the lease if the lessee has drilled or the lessor has received rental payments. ${ }^{96}$

In Federal Oil Co. v. Western Oil Co., ${ }^{97}$ the action was by the lessee in equity to remove the cloud from his title created by the second lease and to prevent the second lessee from drilling on the land. Due to the influence of the doctrine of Venture Oil Co. v. Fretts ${ }^{88}$ and the theory that prospective royalties constituted the sole consideration moving from the lessee for the lease, the court viewed the action as one for specific performance of an executory contract. The initial cash consideration and the monthly payments made by the lessee were entirely disregarded with the result that no consideration remained to support the contract except the probability that the lessee might develop the property. On this premise the court denied the lessee's suit on the ground of lack of mutuality of equitable remedy and on the ground of unfairness. The lease was said to be unfair because the lease stated no term beyond which the lessee might not delay drilling by making monthly payments. This asserted unfairness has found expression

"Pyle v. Henderson (1909) 65 W. Va. 39, 63 S. E. 762; Harness v. Eastem Oil Co. (Igor) 49 W. Va. 250, 38 S. E. 662; Buie v. Porter (I921, Tex. Civ. App.) 228 S. W. 999; Griffin v. Bell (1918, Tex. Civ. App.) 202 S. W. 1034; Tatum v. Fulton (1920, Tex. Civ. App.) 218 S. W. 1088; Patton v. Texas Pac. C. \& O. Co. (1920, Tex. Civ. App.) 225 S. W. 857 ; Morris v. Tex. Pac. C. \& O. Co. (rg2r, Tex. Civ. App.) 228 S. W. 98I; Northwestern O. \& G. Co. v. Branine (1918) 7r Okla. 107, I75 Pac. 533, 3 A. L. R. 344; Magnolia Pet. Co. v. Saylor (Igrg) 72 Okla. 282, I80 Pac. 86I; Carter Oil Co. v. Tiffin (I918, Okla.) 176 Pac. 912; Southwestern Oil Co. v. McDaniel (1918) 7I Okla. 142, I75 Pac. 920; Eastern Oil Co. v. Beatty (I918) 7I Okla. 275, I77 Pac. I04; McCray v. Miller (1919) 78 Okla. 16, I84 Pac. 781; Maud O. \& G. Co. v. Bodkin (I919) 75 Okla. 6, I8o Pac. 959; Pucini v. Bunngarner (1918) 7r Okla. 105, I75 Pac. 537; Shaffer v. Marks, supra note 3 I.

${ }^{95}$ See cases cited supra in notes $87,88$.

${ }^{3}$ Broyles v. Gilman (r920, Tex. Civ. App.) 222 S. W. 685; Canon v. Scott (I921, Tex. Civ. App.) 230 S. W. I042; Hunter v. Gulf Prod. Co. (1919, Tex. Civ. App.) 220 S. W. 163; Heard v. Pratt (1924, Tex. Civ. App.) 257 S. W. 660 ; Houssiere-Latreille Oil Co. v. Jennings-Heywood Synd., supra note 87; Busch Everett Co. v. Vivian Oil Co. (I9II) I28 La. 886, 55 So. 564; McClendon v. Busch Everett Co. (I9r6) I38 La. 722, 70 So. 781; contra: Fed. Oil Co. v. Western Oil Co., supra note 3.

${ }^{87}$ Supra note 63 .

${ }^{98}$ Supra note 47 . 
in some jurisdictions and made grounds of the cancellation of leases by the lessor, ${ }^{99}$ but has been repudiated in others on the ground that the lessor has an implied power of forfeiture for unreasonable delay in drilling. ${ }^{100}$ The question as to whether the action should have been denied because of lack of mutuality of equitable remedy is reserved for discussion elsewhere. ${ }^{101}$ But the original premise of the court, that is, that the lease created contractual relations and that the action was one for specific performance, needs attention.

The courts of Indiana, ${ }^{102}$ Oklahoma, ${ }^{103}$ and Illinois ${ }^{104}$ have followed the Federal Oil Co. case in denying actions by lessees seeking protection of their legal interests as against the lessor and subsequent lessees. A federal court in Illinois made a like decision. ${ }^{105}$ Upon appeal of this case to the Supreme Court, it said:106 "Rightly understood, this is not a suit for specific performance. Its purpose is not to enforce an executory contract to give a lease, or even to enforce an executory promise in a lease already given, but to protect a present vested leasehold, amounting to a freehold interest, from continuing an irreparable injury calculated to accomplish its practical destruction. The complaint is not that performance of some promised act is being withheld or refused, but complainants' vested freehold right is being wrongfully violated and impaired in a way which calls for preventive relief. In this respect the case is not materially different from what it would be if the complainants were claiming under an absolute conveyance rather than a lease. This view of the Supreme Court has been followed in several cases. ${ }^{107}$ Its effect is to bring the courts to a realization that an oil and gas lease after all creates a presently vested interest in land, and that the validity of the instrument creating that interest should not be tested on the basis of consideration as if it were an executory contract, but as a conveyance of land.

\footnotetext{
${ }^{\infty}$ Nat'l O. \& P. L. Co. v. Teel, supra note $55 ;$ Bristow v. Christine O. \& G. Co., supra note 87; Long v. Suln Co., supra note 3.

${ }^{100}$ New American O. \& M. Co. v. Troyer, supra note $3 \mathrm{r}$; Lone Star Gas Co. v McCullough (1920, Tex. Civ. App.) 220 S. W. II 4 ; McKay v. Kilcrease (1920, Tex. Civ. App.) 220 S. W. I77.

${ }^{101}$ See criticism of Ulrey v. Keith, supra note 52 , by Schofield in CoMment (1908-09) 3 ILL. LAw Rev. 43, 601, 608, on this point.

${ }_{102}$ Advance Oil Co. v. Hunt (1917) 66 Ind. App. 228, II6 N. E. 340.

${ }^{203}$ Kolachny v. Galbreath, supra note 48 ; Superior O. \& G. Co. v. Mehlin (I9I0) 25 Okla. 809, I08 Pac. 545; Hill O. \& G. Co. v. White (I9I6) 53 Okla. 748, I57 Pac. 710; Melton v. Cherokee O. \& G. Co. (1917) 67 Okla. 247, I70 Pac. 69I; Lima O. \& G. Co. v. Pritchard, supra note 38 .

${ }^{10 s}$ Ulrey v. Keith, supra note Ior; Watford O. \& G. Co. v. Shipman (Igo8) 233 I11. 9,84 N. E. 53.

${ }^{105}$ Sinith v. Guffey (1912, C. C. A. 7th) 202 Fed. ro6.

${ }^{106}$ Guffey $v_{z}$ Smith, supra note 5I.

${ }^{107}$ Shaffer $v$. Marks, supra note 31; Brumson v. Carter Oil Co., supra note 62; Smith v. McCullough (I922, C. C. A. 8th) 285 Fed. 698; Lindley v. Raydure, supra note 3I; Rich v. Doneghey, supra note 3; Corsciana Pet. Co. v. Owens, supra note 31 .
} 